He advances no new one, but considers that no one theory will account for all the cases, but that there is some truth in all the suggestions. His pathological views are in accordance with those expressed by Treacher Collins at the Ophthalmological Society.

E. E. H.

\title{
CORRESPONDENCE
}

\section{CENTRALBLATT F. PRAK. AUGENHEILKUNDE}

\section{To the Editor of the British JOURnal of Ophthalmology.}

SIR,-When the war broke out Professor Hirschberg, of Berlin, at once removed my name and the names of his other enemy collaborators from the Centralblatt fur praktische Augenheilkunde. At the same time he printed a note regarding the terrible war which its enemies had wickedly brought upon the Vaterland; a note which drew a very forcible rejoinder from Dr. Darier, of Paris, in La Clinique Ophtalmologique. The matter ended there, satisfactorily, as far as I was concerned.

You may imagine my surprise and annoyance to find, on returning to England after eight years absence, and once more seeing copies of the Centralblatt, to find that my name has been printed on its title page, without my consent, since 1915. I have written and requested Professor Hirschberg at once to remove it, and think I may in fairness ask you kindly to print this letter in explanation of my apparent connection with this Journal during four years of war.

$$
\begin{aligned}
& \text { Yours etc., } \\
& \text { F. P. MAYNARD, } \\
& \text { CREWE, } \\
& \text { July, } 1920 .
\end{aligned}
$$

\section{ONE-EYED MOTOR DRIVERS}

To the Editor of the BRITISH JOURNAL OF OPHTHALMOLOGY.

SIR,-The Committee who drew up the report on vision for motor drivers, found considerable difficulty in obtaining evidence of the danger of men who had lost one eye driving motor vehicles.

The following instance, first hand, is direct evidence :

Whilst motoring $I$ was stopped on the road to find a man had been thrown off his motor bicycle and was evidently suffering from a cut head, fractured base, and several other injuries. The man had a glass eye on the right side. As far as I could tell from the history of the accident, he was passing between a cart 
going in the same direction and a motor car passing him in the opposite direction. Apparently his right handle bar had hit the car on the spare tyre which the man was carrying beside the driving seat in the ordinary way for it carried away the hooter on the right handle bar of the bicycle. Evidently the motor cyclist had misjudged his distance from the car owing to the fact that he was blind on the right side.

Harley Street, W.

Yours truly,

M. S. MAYOU. June, 1920 .

\section{BOOK NOTICES}

The Extra Pharmacopoeia. Vol. I. I7th edition. By W. H. Martindale and W. W. Westcott. Pp. ili5. Fcap 8vo, Price 27s net. H. K. Lewis \& Co., Ltd., I36, Gower Street, W.Ci. I920.

That useful, nay indispensable compendium, the Extra Pharmacopoeia, has now reached its seventeenth edition, and under these circumstances nothing need be said as to its well-deserved popularity. The latest ophthalmic products receive adequate mention. It opens with a most patriotic preface, which is worth reading for its own sake.

S. S.

Transactions of the American Ophthalmological Society, IgI9.

Fhiladelphia : published by the Society. T. B. Holloway, Secretary.

This attractive-looking volume of 741 pages, illustrated and carefully indexed, contains an account of the Society's fifty-fifth annual meeting held at Atlantic City in June, 1819. The large size of the book is largely accounted for by the fact that it includes the theses, some of which are rather long, of candidates for admission to the Society. It begins with an account of R. A. Reeve, who died on January 22, 1919, and appended is a speaking portrait of our esteemed colleague. Many of the papers it contains will be noticed in abstract form in our columns.

S. S.

The Ophthalmic Year Book. 'March, 1920. Vol. 16. Part I. Published quarterly by the Ophthalmic Publishing Company, 318, Majestic Building, Denver, Colorado. Annual subscription, ten dollars in advance.

As readers will doubtless recall, the Ophthalmic Year Book maintained for thirteen years a separate existence, at the end of which time it was absorbed by the American Journal of Ophthalmology, and appeared as an integral part of that Journal. It now reaches us as a separate quarterly periodical, stated on its cover as 